\title{
Role of excitatory amino acid pathways in control of gonadotrophin secretion in adult female rats sterilized by neonatal administration of oestradiol or testosterone
}

\author{
L. Pinilla, M. Tena-Sempere and E. Aguilar* \\ Department of Physiology, Faculty of Medicine, Córdoba University, 14004 Córdoba, Spain
}

\begin{abstract}
Administration of sex steroids to neonatal female rats resulted in anovulation and absence of positive and negative feedback between oestradiol and LH secretion. In the present experiments, the role of excitatory amino acids in the control of gonadotrophin secretion in anovulatory adult rats sterilized by neonatal administration of oestradiol benzoate or testosterone propionate (100 mg or $1.25 \mathrm{mg}$ on the day of birth, respectively) was studied. Cyclic females in metoestrus were used as controls. Serum LH and FSH concentrations were measured at different times after i.p. administration of $N$-methyl-D-aspartic acid (NMDA), kainic acid (agonists of NMDA and kainate receptors, respectively), MK-801 or 6,7dinitroquinoxaline-2,3-dione (DNQX) (antagonists of NMDA and kainate receptors, respectively). Experiments were also performed in control and sterilized females I week after ovariectomy. It was found that: (1) the effectiveness of NMDA and kainic acid in stimulating LH secretion was significantly higher in sterilized than in cyclic females; (2) ovariectomy increased LH secretion only in control females; (3) the stimulatory effect of NMDA and kainic acid on $\mathrm{LH}$ secretion after ovariectomy was observed only in sterilized females; (4) MK-801 and DNQX selectively decreased LH secretion in sterilized females; and (5) FSH secretion remained unaffected after NMDA or kainic acid administration in both control and sterilized females. In conclusion, the results obtained in sterilized females showed both a tonic release of endogenous excitatory amino acids and a greater responsiveness to NMDA and kainic acid than in controls.
\end{abstract}

\section{Introduction}

Growing evidence indicates a crucial role of excitatory amino acids (EAAs) in the regulation of pituitary hormone secretion (Brann and Mahesh, 1992a, 1994; Cowell 1993). The action of EAAs is mediated by activation of different subtypes of postsynaptic receptors, which include $N$-methyl-D-aspartate (NMDA) receptors, kainate receptors, 2-amino-3-hydroxy-5methyl-4-isoxazol propionic acid (AMPA) receptors, amino-4phosphobutyric acid (L-AP4) receptors and metabotropic receptors. NMDA and kainate receptors are activated specifically by NMDA and kainic acid (KA), respectively, and antagonized by MK-801 (Foster and Wong, 1987) and 6,7dinitroquinoxaline-2,3-dione (DNQX) (Honoré et al., 1988), respectively. In female rats, systemic administration of NMDA or KA stimulates the secretion of $\mathrm{LH}$ in prepubertal and adult female rats (Abbud and Smith, 1991; Carbone et al., 1992; MacDonald and Wilkinson, 1992; Luderer et al., 1993). The effects of NMDA and KA on FSH secretion have not been as well studied as their effects on LH release. The physiological effects of NMDA and KA appear to be influenced by endocrine

*Correspondence.

Revised manuscript received 26 November 1997. environments. For instance, inhibitory actions of NMDA on LH secretion have been described in ovariectomized females (Brann and Mahesh, 1992b; Luderer et al., 1993).

In rats, the functionality of the adult hypothalamicpituitary-ovarian axis depends on the steroid milieu immediately after birth. Neonatal administration of oestrogens or androgens to female rats induced anovulation (Barraclough, 1961; Gorski 1963), abolished the positive feedback between oestrogens and LH (Mennin and Gorski, 1975; Harlan and Gorski 1977; Aguilar et al., 1983) and reduced gonadotrophin secretion after ovariectomy (Aguilar et al, 1984). The precise mechanisms involved in these effects have not been completely characterized, although many changes in the functionality of the noradrenergic (Lookingland et al., 1982), dopaminergic (Demarest et al., 1981), serotoninergic (Collado and Aguilar, 1993) and opiatergic (Grossmann et al., 1987) systems have been identified.

The role of EAAs in LH release in anovulatory females remains controversial. Liaw and Barraclough (1993) described the decrease in responsiveness to NMDA in androgensterilized female rats. Since a preliminary study reported a greater effectiveness of NMDA in increasing LH secretion in oestradiol-sterilized female rats (Pinilla et al, 1994), it was hypothesized that altered gonadotrophin secretion in sterilized 
females is probably due to changes in the release of EAAs rather than to a decrease in the effectiveness of EAAs. The present experiments were carried out to confirm this hypothesis. LH and FSH responses after systemic administration of NMDA and KA in female rats sterilized by neonatal injections of oestradiol or testosterone were studied. Both models of sterilized animals were selected since, although it has been proposed that neonatal effects of testosterone develop after its aromatization to oestradiol (Naftolin et al., 1973), the presence of androgen receptors in the neonatal hypothalamus (Vito and Fox, 1982) and the ability of $5 \beta$-dihydrotestosterone to masculinize the feminine brain (Arai et al., 1981) suggest possible differences in the effects of neonatal androgen and oestrogen administration (Vaticon et al., 1985; Collado and Aguilar, 1993).

Since it has been suggested that an inhibitory effect of NMDA on GnRH predominates over its own stimulatory action in ovariectomized females (Brann and Mahesh, 1992b; Luderer et al., 1993), a second aim of the present study was to analyse the effects of NMDA and KA on gonadotrophin secretion in ovariectomized control and sterilized females.

\section{Materials and Methods}

\section{Animals and drugs}

Female Wistar rats born in the authors' colony were used. The day on which animals were born was considered as day 1 . On day $I$, the litter size was adjusted to eight pups per dam, and the animals were injected with oestradiol benzoate or testosterone propionate ( $100 \mu \mathrm{g}$ or $1.25 \mathrm{mg}$, respectively, dissolved in $0.1 \mathrm{ml}$ olive oil) or vehicle. The animals were weaned at 21 days of age and housed in groups of four or five per cage. Animals were maintained under controlled conditions of temperature $\left(20^{\circ} \mathrm{C}\right)$ and light $(12 \mathrm{~h}$ light: $12 \mathrm{~h}$ darkness) with free access to pelleted food (Panlab, Barcelona) and tap water. After vaginal opening, vaginal smear cycles were monitored daily. Only control females showing regular cycles were used. Oestrogenized females showed persistent oestrous vaginal smears, while the vaginal membrane was closed in androgenized females. Rats in metoestrus were selected as controls since animals present the greatest responses to NMDA in this phase of the cycle (Luderer et al., 1993). The experiments commenced at 10:00 h when animals were approximately 90 days of age. Blood samples were obtained by decapitation and pituitaries and hypothalami were removed for use in other studies.

Oestradiol benzoate, testosterone propionate, NMDA and KA were from Sigma (Barcelona). The NMDA antagonist, MK-801, was from Research Biomedical International (RBI, Natick, MA). The kainate antagonist DNQX was obtained from Tocris Neuramin (Essex). NMDA, KA and MK-801 were dissolved immediately before use in saline. DNQX were suspended in saline after gentle agitation.

\section{Experimental protocols}

Experiment 1. Cyclic females in the metoestrous phase and sterilized females were injected i.p. with vehicle, NMDA (15 or
$30 \mathrm{mg} \mathrm{kg}^{-1}$ ) and $\mathrm{KA}\left(2.5\right.$ or $15 \mathrm{mg} \mathrm{kg}^{-1}$ ) and blood samples were obtained by decapitation at $0,5,15,30$ and $45 \mathrm{~min}$.

Experiment 2. Cyclic females in the metoestrous phase and oestrogenized females were killed after i.p. injection with vehicle, MK-801 (1 mg kg-1) or DNQX (I mg kg-1) at $-60 \mathrm{~min}$, and with vehicle, NMDA (15 $\left.\mathrm{mg} \mathrm{kg}^{-1}\right)$, or KA $\left(15 \mathrm{mg} \mathrm{kg}^{-1}\right)$ at $-15 \mathrm{~min}$ to determine whether the NMDA and KA effects were mediated by their specific receptors. Blood samples were obtained by decapitation at $0 \mathrm{~min}$.

Experiment 3. Cyclic and sterilized females were ovariectomized under light ether anaesthesia to determine whether the stimulatory effect of NMDA and KA on LH release changes to an inhibitory action in ovariectomized animals (Brann and Mahesh, 1992b; Luderer et al., 1993). Ovariectomized females were implanted with Silastic capsules (Dow Corning, Midland, MI; length $10.0 \mathrm{~mm}, 1.519 \mathrm{~mm}$ inner diameter; 3.060 outer diameter) with or without oestradiol benzoate. The animals were decapitated a week later $15 \mathrm{~min}$ after administration of NMDA (15 $\mathrm{mg} \mathrm{kg}^{-\mathrm{I}}$ ) or KA (15 mg $\mathrm{kg}^{-1}$ ).

Experiment 4. Cyclic and oestrogenized females were ovariectomized or sham-ovariectomized and a week later decapitated $60 \mathrm{~min}$ after i.p. administration of vehicle, MK-801 or DNQX ( $\left.1 \mathrm{mg} \mathrm{kg}^{-1}\right)$ to determine their effects in sterilized females.

\section{Hormone measurements}

After centrifugation $\left(1650 \mathrm{~g}\right.$ at $4^{\circ} \mathrm{C}$ for $\left.20 \mathrm{~min}\right)$, serum was collected, frozen, and stored at $-20^{\circ} \mathrm{C}$ until use. The concentrations of LH and FSH were measured in duplicate in $25-50 \mu \mathrm{l}$ using a double-antibody method and using radioimmunoassay kits supplied by NIH (Bethesda, MD). Rat LH I-9 and rat FSH-l-8 were labelled with ${ }^{125}$ I by the Chloramine T method (Greenwood et al., 1963). Hormone concentrations were expressed as $\mathrm{ng} \mathrm{ml}^{-1}$ of serum of the reference preparations LH-rat-RP-2 and FSH-rat-RP-3, respectively. The intra-assay coefficients of variations were $6 \%$ and $7 \%$ for $\mathrm{LH}$ and $\mathrm{FSH}$, respectively. The interassay variabilities were $<12 \%$. The sensitivities were $0.075 \mathrm{ng} \mathrm{ml}^{-1}$ and $0.4 \mathrm{ng} \mathrm{ml}^{-1}$ for $\mathrm{LH}$ and $\mathrm{FSH}$, respectively. In some experiments oestradiol and progesterone were measured using kits from Diagnostics Products Corp. (Los Angeles, CA) with a sensitivity of 1 and $10 \mathrm{pg}$ per tube, respectively. All samples were analysed in the same assay and the intra-assay coefficients of variation were $6 \%$.

\section{Statistical analysis}

All results are expressed as mean \pm SEM. Data were analysed by one-factor or two-factors analysis of variance (ANOVA) followed by Tukey's test. In Expt 1, the serum LH and FSH concentrations at each time after NMDA or KA administration were analysed by repeated one-factor ANOVA, and the 

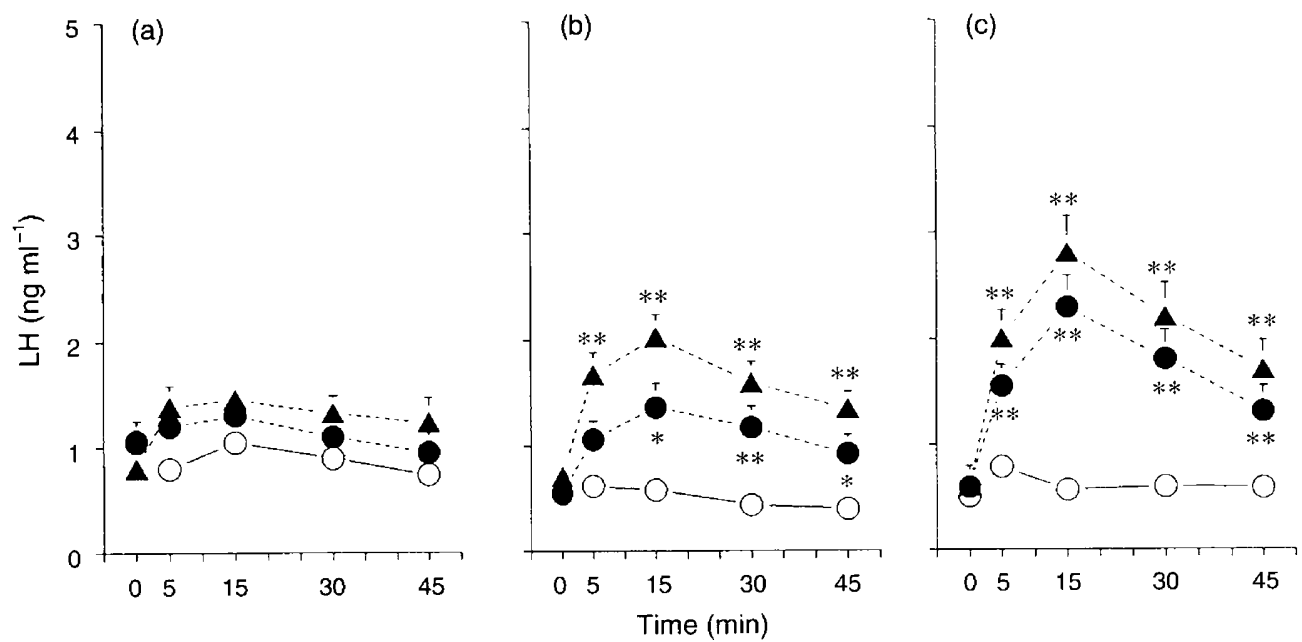

Fig. 1. Serum concentrations of LH in (a) cyclic, (b) androgenized and (c) oestrogenized female rats killed at different times after injection with vehicle $(O)$ or of $N$-methyl-D-aspartic acid (NMDA;, $15 \mathrm{mg} \mathrm{kg}^{-1} ; \boldsymbol{\Lambda}$. $30 \mathrm{mg} \mathrm{kg}^{-1}$ ). Values are means \pm SEM of $8-12$ animals per group (the SEM is not given when the bar is smaller than the symbols). ${ }^{*} P<0.05$. ${ }^{* *} P \leq 0.01$ versus corresponding vehicle-injected group (ANOVA and Tukey's test).

differences between administration of vehicle and different drugs during the 45 min of sampling by a two-way ANOVA followed by Tukey's test.

\section{Results}

\section{Effects of NMDA and KA on LH and FSH secretion in intact} females (Expt 1)

Serum progesterone concentrations were significantly lower $(P \leq 0.001)$ in androgenized $\left(7.54 \pm 1.34 \mathrm{ng} \mathrm{ml}^{-1}, n=36\right)$ and oestrogenized $\left(8.89 \pm 1.35 \mathrm{ng} \mathrm{ml}^{-1}, n=30\right)$ females than in the cyclic group $\left(37.96 \pm 7.27 \mathrm{ng} \mathrm{ml}^{-1}, n=34\right)$, while no significant differences were observed in oestradiol concentrations. Serum LH concentrations were lower $(P \leq 0.001)$ in androgenized $\left(0.61 \pm 0.04 \mathrm{ng} \mathrm{ml}^{-1}\right)$ and oestrogenized females $\left(0.51 \pm 0.03 \mathrm{ng} \mathrm{ml}^{-1}\right)$ than in cyclic $\left(1.05 \pm 0.08 \mathrm{ng} \mathrm{ml}^{-1}\right)$ females. The serum $\mathrm{LH}$ concentrations in cyclic females at each time after administration of NMDA ( 15 and $30 \mathrm{mg} \mathrm{kg}^{-1}$ ) or vehicle were similar (one-way ANOVA) (Fig. 1). However, the concentrations for $45 \mathrm{~min}$ were higher after treatment with NMDA $\left(30 \mathrm{mg} \mathrm{kg}^{-1}\right.$ ) than after treatment with vehicle $(F=16.30, P \leq 0.05$, two-way ANOVA), although the interaction between time and treatment was not significant $(F=0.14)$. Serum $\mathrm{LH}$ concentrations remained unaffected in cyclic females after administration of KA (2.5 and $15 \mathrm{mg} \mathrm{kg}^{-1}$ ) (Fig. 2).

In sterilized females, a significant increase in serum LH concentrations was observed after administration of NMDA ( 15 and $30 \mathrm{mg} \mathrm{kg}^{-1}$ ) and KA ( $15 \mathrm{mg} \mathrm{kg}^{-1}$ ) (Figs 1 and 2). Since basal LH concentrations were different in cyclic and sterilized females, the LH responses $15 \mathrm{~min}$ after NMDA and $\mathrm{KA}$ administration in terms of change over concentrations in corresponding groups injected with vehicle are shown as an example (Fig. 3). LH responses to NMDA (15 and $30 \mathrm{mg}$ $\mathrm{kg}^{-1}$ ) and $\mathrm{KA}$ ( $15 \mathrm{mg} \mathrm{kg}^{-1}$ ) were enhanced in sterilized females (Fig. 3).
Serum FSH concentrations were similar in cyclic $\left(4.07 \pm 0.20 \mathrm{ng} \mathrm{ml}^{-1}\right)$, androgenized $\left(4.43 \pm 0.26 \mathrm{ng} \mathrm{ml}^{-1}\right)$ and oestrogenized $\left(3.74 \pm 0.19 \mathrm{ng} \mathrm{ml}^{-1}\right)$ females. Administration of NMDA or KA did not change the serum FSH concentrations significantly in either cyclic or sterilized females (data not shown).

Effects of pretreatment with $M K-801$ and DNQK on NMDA and $K A$ actions in $L H$ and FSH secretion (Expt 2)

In this experiment, serum LH concentrations remained unchanged in cyclic females $15 \mathrm{~min}$ after administration of NMDA or KA ( $15 \mathrm{mg} \mathrm{kg}^{-1}$ ) either in the absence or presence of MK-801 or DNQX (Fig. 4). In oestrogenized females, the NMDA-stimulated LH release was blocked selectively by MK-801 but not by DNQX. The stimulatory effect of KA was blocked by DNQX but not by MK-80I (Fig. 4).

Serum FSH concentrations after combined administration of NMDA plus MK801, NMDA plus DNQX, KA plus MK801 or KA plus DNQX were similar to those after vehicle injection both in cyclic and oestrogenized females (data not shown).

\section{Effects of NMDA and KA on LH and FSH secretion in ovariectomized females (Expt 3)}

Serum oestradiol concentrations were similar in cyclic and androgenized females either intact $\left(48 \pm 3.4 \mathrm{ng} \mathrm{ml}^{-1}\right.$ versus $56 \pm 4.6 \mathrm{ng} \mathrm{ml}^{-1}$ ) or ovariectomized and treated with oestradiol $\left(269 \pm 43 \mathrm{ng} \mathrm{ml}^{-1}\right.$ versus $219 \pm 24 \mathrm{ng} \mathrm{ml}^{-1}$ ). Serum LH concentrations in control females increased significantly $(P \leq 0.01) 1$ week after ovariectomy and returned to concentrations below that of the intact group after oestradiol replacement. Administration of NMDA ( $15 \mathrm{mg} \mathrm{kg}^{-1}$ ) or KA $\left(15 \mathrm{mg} \mathrm{kg}{ }^{-1}\right)$ stimulated LH release only in ovariectomized females treated with oestradiol (Fig. 5). 

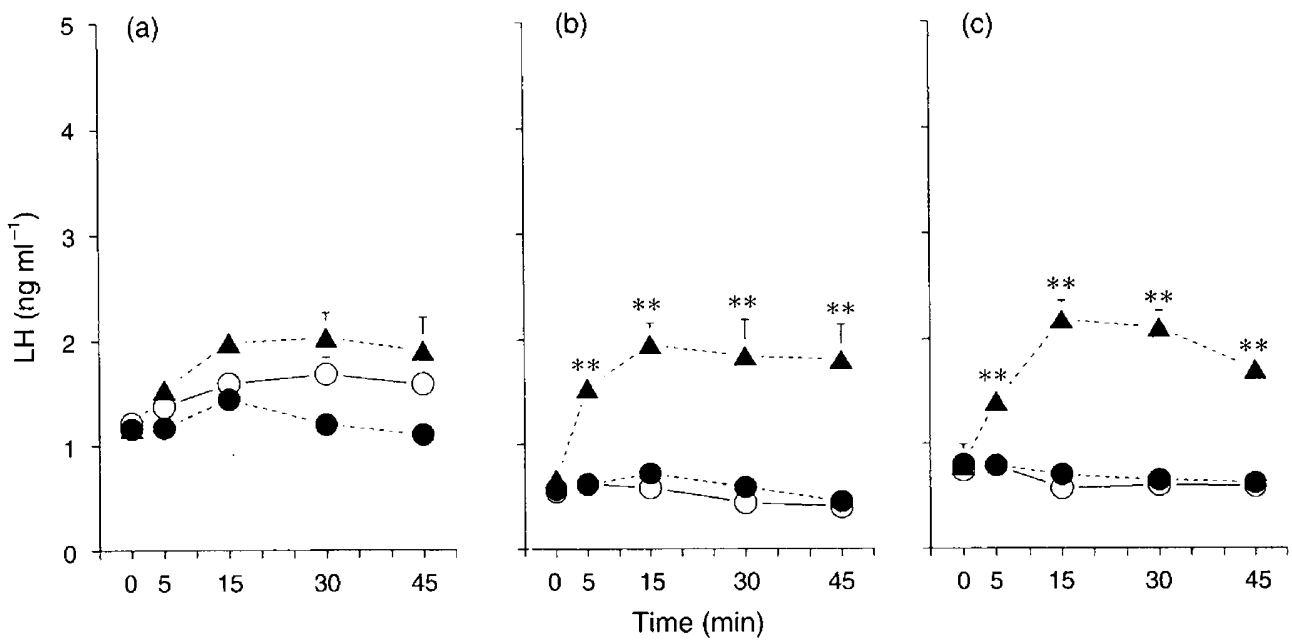

Fig. 2. Serum concentrations of LH in (a) cyclic, (b) androgenized and (c) oestrogenized female rats killed at different times after injection with vehicle $(\mathrm{O})$ or kainic acid (KA;, $2.5 \mathrm{mg} \mathrm{kg}^{-1} ; \boldsymbol{\Lambda}, 15 \mathrm{mg} \mathrm{kg}^{-1}$ ). Values are means \pm SEM of 8-12 animals per group (the SEM is not given when the bar is smaller than the symbols). ${ }^{* * P} \leq 0.01$ versus corresponding vehicle-injected group (ANOVA and Tukey's test).

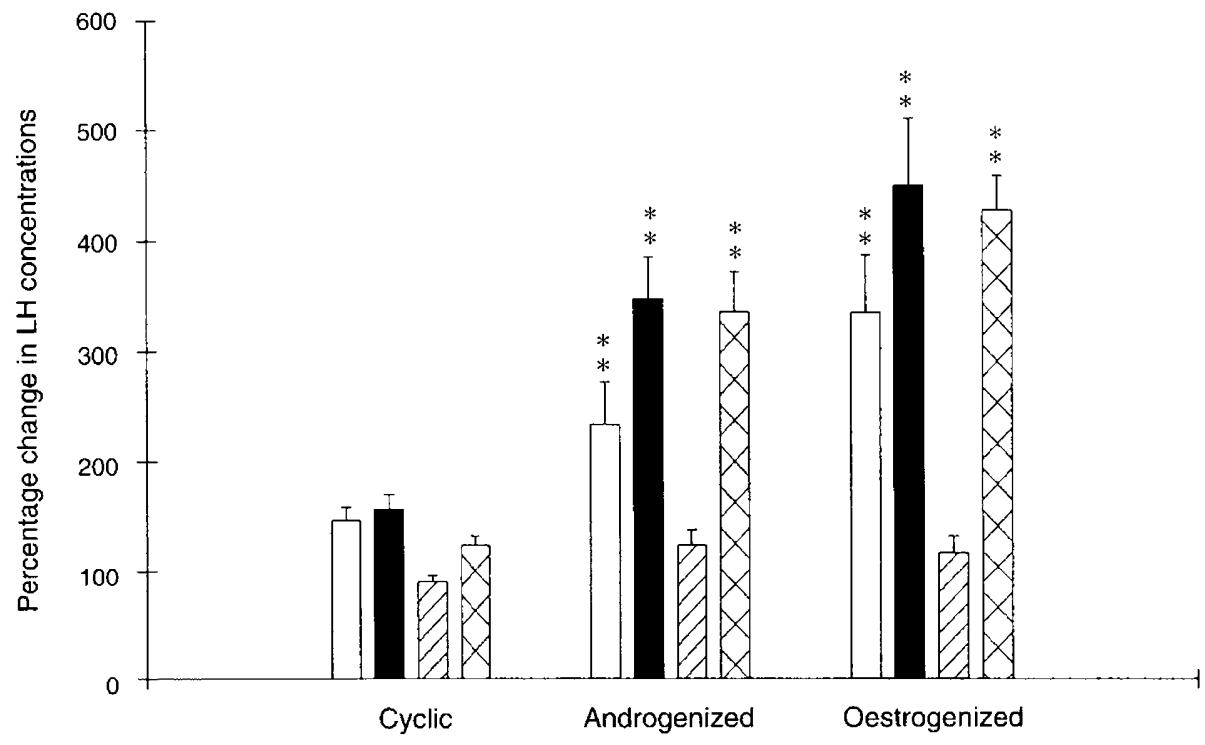

Fig. 3. Effects of of $N$-methyl-D-aspartic acid (NMDA; $\square, 15 \mathrm{mg} \mathrm{kg}^{-1} ; \mathbf{\square}, 30 \mathrm{mg} \mathrm{kg}^{-1}$ ) and kainic acid $\left(\mathrm{KA}_{;} \oslash, 2.5 \mathrm{mg} \mathrm{kg}^{-1}\right.$; $15 \mathrm{mg} \mathrm{kg}^{-1}$ ) on $\mathrm{LH}$ secretion in cyclic, androgenized and oestrogenized female rats. Data obtained $15 \mathrm{~min}$ after drug injection are expressed as changes over concentrations in corresponding groups injected with vehicle. ${ }^{*} P \leq 0.01$ versus corresponding vehicle-injected group (ANOVA and Tukey's test).

In androgenized and oestrogenized females, only insignificant changes in serum $\mathrm{LH}$ concentrations were observed after either ovariectomy or oestradiol replacement, while NMDA and KA enhanced LH secretion in all groups of sterilized females (Fig. 5).

Serum FSH concentrations increased significantly $(P \leq 0.01)$ in cyclic females a week after ovariectomy (from $5.15 \pm 0.15 \mathrm{ng}$ $\mathrm{ml}^{-1}$ to $35.74 \pm 1.75 \mathrm{ng} \mathrm{ml}^{-1}$ ) and remained unchanged 15 min after treatment with NMDA or KA ( $\left.15 \mathrm{mg} \mathrm{kg}^{-1}\right)$. The increase in FSH secretion after ovariectomy was blunted in oestrogenized (Table I) and androgenized females (data not shown). The only significant effect of NMDA and KA administration on FSH secretion by sterilized females was an increase in females ovariectomized and oestrogenized after KA treatment (data not shown).

Effects of MK-801 and DNQX in intact and ovariectomized females (Expt 4)

In control females (intact or ovariectomized), serum LH and FSH concentrations did not change after MK-801 or DNQX administration. In contrast, MK-801 and DNQX inhibited LH secretion in intact females that were ovariectomized and 


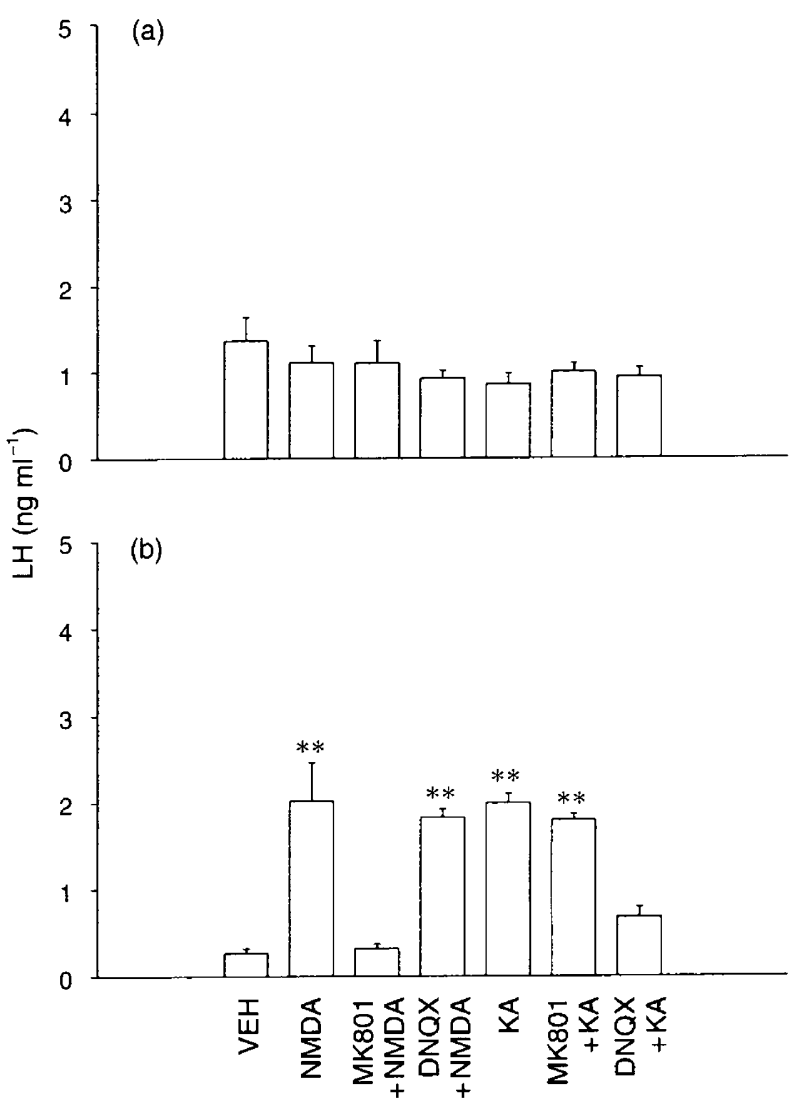

Fig. 4. Serum concentrations of LH in (a) cyclic and (b) oestrogenized female rats killed $15 \mathrm{~min}$ after injection with vehicle, of $N$-methyl-Daspartic acid (NMDA; $15 \mathrm{mg} \mathrm{kg}^{-1}$ ) or kainic acid (KA; $2.5 \mathrm{mg} \mathrm{kg}^{-1}$ ). Groups of animals injected with NMDA or KA were pretreated $60 \mathrm{~min}$ before decapitation with vehicle, MK-801 (1 mg kg ${ }^{-1}$ ) or 6,7-dinitroquinoxaline-2,3-dione (DNQX; $\mathrm{I} \mathrm{mg} \mathrm{kg}{ }^{-1}$ ). Values are means \pm SEM of ten animals per group. ${ }^{* *} P \leq 0.01$ versus corresponding vehicle-injected group (ANOVA and Tukey's test).

oestrogenized. In addition, MK-801 and DNQX decreased serum FSH concentrations in intact oestrogenized females (Table 1).

\section{Discussion}

The results of the present study show that NMDA and KA stimulate LH secretion efficiently in adult sterilized females. The consistency of this finding is supported by its observation at different times after administration of different doses of NMDA in intact and ovariectomized groups and by the specificity of drug action, since the effects of NMDA and KA were abolished by selective antagonists (MK-801 blocked the effects of NMDA, and DNQX those of KA). In cyclic females, NMDA ( $30 \mathrm{mg} \mathrm{kg}^{-1}$ ) induced a weak LH response that was only significant when comparing the serum $\mathrm{LH}$ concentrations during the $45 \mathrm{~min}$ after NMDA or vehicle administration. A deficient response to NMDA in adulthood has been reported in female (Arias et al., 1993) and male rats (Pinilla et al., 1995). This may be due to the combination of: (a) the low dose used (Mason et al., 1983); (b) the time elapsed between NMDA injection and sampling, since the stimulatory effect of NMDA on LH release is very transient (Price et al., 1978; Schainker and Cicero, 1980; Urbanski and Ojeda, 1987); and (c) the age of the animal, since the effectiveness of NMDA decreases after puberty in male (Pinilla et al., 1995) and female rats (MacDonald and Wilkinson, 1992).

Since responsiveness to NMDA and KA does occur in ovariectomized, oestradiol-implanted non-sterilized females, it is possible that ovariectomy takes away a system (perhaps progesterone) that inhibits expression of LH secretion in response to EAA agonists and opens the possibility that for the role of NMDA and KA to have an affect on LH secretion needs a state of high oestradiol and low progesterone concentrations are required. This hypothesis is supported by the effectiveness of NMDA in sterilized females, groups with low progesterone concentrations (Lookingland et al., 1982 and present results) and in control females ovariectomized (to reduce progesterone concentrations) and treated with oestradiol.

The present data differ from those of Liaw and Barraclough (1993) which showed that NMDA increased LH secretion in control females more effectively than it did in androgenized females. This discrepancy may be due to differences in the steroid concentrations between the experimental designs, since Liaw and Barraclough compared the NMDA effects in the absence of progesterone (ovariectomized control and androgenized females were treated for $48 \mathrm{~h}$ with oestradiol). The results of the present study strongly suggest that GnRH neurones of sterilized females retain their ability to respond after appropriate stimuli, such as activation of NMDA and KA receptors, which extends previous observations showing that electrical activation of the ventral noradrenergic tract, and administration of naloxone or NMDA increased LH secretion more effectively in sterilized than in control females (Dyer and Mansfield, 1985; Grossmann et al., 1987; Pinilla et al., 1994).

The higher effectiveness of NMDA and KA to stimulate LH release in sterilized females may be explained by the release of greater amounts of GnRH by NMDA and KA in sterilized than in control females, a consequence of the increased releasable pool of GnRH in females injected neonatally with sex steroids (King et al., 1980; Dyer and Mansfield, 1985), or by the increase in the number or affinity of the NMDA and KA receptors governing $\mathrm{GnRH}$ secretion. In addition, since the pituitary gland has been identified as a target for NMDA and KA actions, stimulating $\mathrm{GH}$ and gonadotrophin secretion directly (Lindström and Ohlsson, 1992; Zanisi et al., 1994), possible differences in pituitary responses to NMDA and KA between cyclic and sterilized females cannot be ruled out.

Aspartate and glutamate are released in the preoptic area (Jarry et al., 1992; Ping et al., 1994a) and play a crucial role in the generation of ovulatory LH surges and in LH secretion after gonadectomy (López et al., 1990; Brann and Mahesh, 1991; Brann et al., 1993; Ping et al., 1994b). Since basal release of EAAs takes place in sterilized females (as evidenced by the selective decrease in LH and FSH secretion after the blockade of NMDA and KA receptors) and NMDA and KA stimulated LH secretion more effectively in sterilized than in control females, the absence of ovulatory LH surges and LH responses after ovariectomy in sterilized females might be explained if the increase in hypothalamic EAAs released during the positive and negative feedback actions of ovarian steroids did not occur 

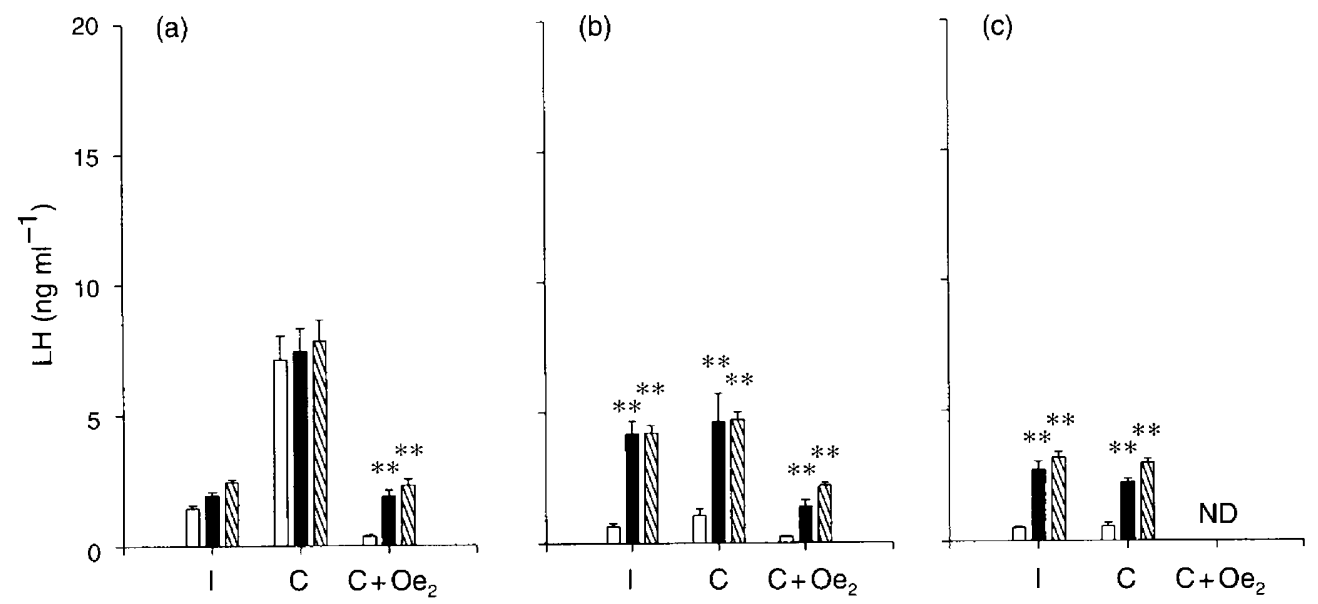

Fig. 5. Serum concentrations of LH in (a) cyclic, (b) androgenized and (c) oestrogenized female rats that were intact, ovariectomized or ovariectomized $(\mathrm{C})$ and treated with oestradiol $\left(\mathrm{Oe}_{2}\right)$. Animals were sacrificed 15 min after treatment with vehicle ( $\square$ ), N-methyl-D-aspartic acid (NMDA; $\mathbf{\square}, 15 \mathrm{mg} \mathrm{kg}^{-1}$ ) or kainic acid $\left(\mathrm{KA} ; \otimes, 15 \mathrm{mg} \mathrm{kg}^{-1}\right)$. Values are means \pm SEM of $8-10$ animals per group. ${ }^{*} P \leq 0.01$ versus corresponding vehicle-injected group (ANOVA and Tukey's test).

Table 1. Serum LH and FSH concentrations (ng $\mathrm{ml}^{-1}$ ) in intact and ovariectomized control and oestrogenized females killed $60 \mathrm{~min}$ after administration of vehicle, MK-801 (1 mg kg${ }^{-1}$ ) or 6,7dinitroquinoxaline-2,3-dione (DNQX) $\left(1 \mathrm{mg} \mathrm{kg}^{-1}\right)$

\begin{tabular}{lccccc}
\hline & \multicolumn{2}{c}{ Intact } & & \multicolumn{2}{c}{ Ovariectomized } \\
\cline { 2 - 3 } \cline { 5 - 6 } Treatment & LH & FSH & & LH & FSH \\
\hline Controls & & & & \\
Vehicle & $1.06 \pm 0.10$ & $5.15 \pm 0.15$ & & $2.76 \pm 0.32$ & $35.6 \pm 1.75$ \\
MK-801 & $0.96 \pm 0.07$ & $5.02 \pm 1.12$ & & $3.10 \pm 0.50$ & $37.7 \pm 2.38$ \\
DNQX & $0.89 \pm 0.07$ & $4.49 \pm 0.63$ & & $3.20 \pm 0.40$ & $36.6 \pm 1.85$ \\
Oestrogenized & $0.51 \pm 0.08$ & $6.40 \pm 0.04$ & & $0.56 \pm 0.14$ & $10.21 \pm 0.04$ \\
Vehicle & $0.13 \pm 0.03^{* *}$ & $3.10 \pm 0.60^{* *}$ & & $0.23 \pm 0.08^{\mathrm{a}}$ & $14.30 \pm 1.60$ \\
MK-801 & $0.13 \pm 0.03^{* *}$ & $3.10 \pm 0.30^{* *}$ & & ND & $13.25 \pm 1.30$ \\
DNQX & & & & \\
\hline
\end{tabular}

Values are means $\pm \mathrm{SEM}$ of ten animals per group. ${ }^{* *} P \leq 0.01$ versus corresponding vehicle-injected group (ANOVA followed by Tukey's test). ${ }^{2}$ Only six rats were included in the LH mean, since hormone concentrations in the four others were undetectable. ND: not detectable.

in sterilized females. The absence of response to MK-801 and DNQX in cyclic females may be caused by a lower basal release of EAAs or by a lower releasable pool of GnRH. Serial blood sampling, as Ping et al. (1994b) used in males, will be necessary to detect the effects of MK-80I and DNQX in control ovariectomized females.

NMDA inhibits LH secretion in ovariectomized female rats (Brann and Mahesh 1992b; Luderer ef al., 1993). This action has been explained by the release of an unknown factor inhibitory to GnRH or LH secretion. The results of the present study do not support this hypothesis, since ovariectomy did not abolish the NMDA and KA effects in sterilized females, and the responsiveness to NMDA and KA was observed in ovariectomized, oestradiol implanted non-sterilized females.

In conclusion, although hypothalamic release of EAAs was not measured, the results of the present study strongly suggest that basal release of EAAs takes place in sterilized females and indicate that NMDA and $\mathrm{KA}$ induce $\mathrm{LH}$ release more effectively in sterile than in cyclic females.

This work was supported by grant PM95-0112 (DGICYT, Spain). The authors gratefully acknowledge the NIDDK (Bethesda, MD) for supplying materials for $\mathrm{LH}$ and FSH radioimmunoassays. The authors are indebted to M. Sullivan for assistance in the revision of the manuscript.

\section{References}

Abbud R and Smith MS (1991) Differences in the luteinizing hormone and prolactin responses to multiple injections of kainate, as compared to $N$-methyl-D,L-aspartate, in cycling rats Endocrinology 129 3254-3258

Aguilar E, Fernández-Galaz C, Vaticón MD, Tejero A and Oriol A (1983) Oestrogen-bromocriptine interaction in the control of luteinizing hormone and prolactin secretion in the neonatally oestrogenized female rat Journal of Endocrinology 97 319-325 
Aguilar E, Tejero A, Vaticon MD and Fernández Galaz C (1984) Dissociation of luteinizing hormone and follicle-stimulating hormone control mechanisms in male and female rats by neonatal administration of estradiol benzoate or testosterone propionate Hormone Research 19 106-116

Arai Y, Yemanouchi K, Mizukami S, Yanai R, Shibata K and Nagasawa H (1981) Induction of anovulatory sterility by neonatal treatment with 5 $\beta$-dihydrotestosterone Acta Endocrinologica 96 439-443

Arias P, Jarry H, Leonhardt S, Moguilevski J and Wuttke W (1993) Estradiol modulates the LH release response to $\mathrm{N}$-methyl-D-aspartate in adult female rats: studies on hypothalamic luteinizing hormone releasing hormone and neurotransmitter release Neuroendocrinology 57 710-715

Barraclough CA (1961) Production of anovulatory sterile rats by single injections of testosterone propionate Endocrinology 66 62-67

Brann DW and Mahesh VB (1991) Endogenous excitatory amino acid regulation of the progesterone-induced LH and FSH surge in estrogen-primed ovariectomized rats Neuroendocrinology 53 107-110

Brann DW and Mahesh VB (1992a) Excitatory amino acid neurotransmission: evidence for a role in neuroendocrine regulation Trends in Endocrinology and Metabolism 3 122-126

Brann DW and Mahesh VB (1992b) Excitatory amino acid regulation of gonadotropin secretion: modulation by steroid hormones Joumal of Steroid Biochemistry and Molecular Biology 41 847-850

Brann DW and Mahesh VB (1994) Excitatory amino acids: function and significance in reproduction and neuroendocrine regulation Frontiers in Neuroendocrinology 15 3-49

Brann DW, Ping L and Mahesh VB (1993) Role of non-NMDA receptor neurotransmission in steroid and preovulatory gonadotropin surge expression in the female rat Molecular and Cellular Neuroscience 4 292-297

Carbone S, Szwarcfarb B, Losada M and Moguilevski J (1992) Effects of ovarian steroids on the gonadotrophin response to $N$-methyl-D-aspartate and on hypothalamic excitatory amino acid levels during sexual maturation in female rats Endocrinology 130 1365-1370

Collado D and Aguilar E (1993) Further evidence that prolactin secretion in adult female rats is differently modified after neonatal estrogenization or androgenization: responses to methysergide, quipazine and pizotifen Physiology and Behavior 53 161-165

Cowell AM (1993) Excitatory amino acids and hypothalamic-pituitarygonadal function Journal of Endocrinology 139 177-182

Demarest KT, McDay DW, Riegle GD and Moore KE (1981) Sexual differences in tuberoinfundibular dopamine nerve activity induced by neonatal androgen exposure Neuroendocrinology 32 108-113

Dyer RG and Mansfield S (1985) Neonatal exposure to testosterone potentiates electrically stimulated gonadotrophin secretion in adult female rats Journal of Physiology 37753

Foster AC and Wong E (1987) The novel anticonvulsant MK-801 binds to the activated state of the $\mathrm{N}$-methyl-D-aspartate receptor in the brain British Journal of Pharmacology 91 403-409

Gorski RA (1963) Modifications of ovulatory mechanisms by postnatal administration of estrogen to the rat American Journal of Physiology 205 842-844

Greenwood FC, Hunter WM and Glover IS (1963) The preparation of 131-1labelled human growth hormone of high specific radioactivity Biochemical Journal 89 114-123

Grossmann R, Diez-Guerra FJ, Mansfield S and Dyer RG (1987) Neonatal testosterone modifies LH secretion in the adult female rat by altering the opioid-noradrenergic interaction in the medial preoptic area Brain Research 415 205-210

Harlan RE and Gorski R (1977) Steroid regulation of luteinizing hormone secretion in normal and androgenized rats at different ages Endocrinology $101741-749$

Honoré T, Davies SBN, Drejer J, Fletcher EJ, Jacobsen P, Lodge D and Nielsen FE (1988) Quinoxalinediones: potent competitive non-NMDA glutamate receptor antagonists Science $\mathbf{2 4 1}$ 701-703
Jarry H, Hirsch B, Leonhardt S and Wuttke W (1992) Amino acid neurotransmitter release in the preoptic area of rats during the positive feedback actions of estradiol on LH release Neuroendocrinology 56 133-140

King JC, Tobet SA, Snavely FL and Arimura AA (1980) The LHRH system in normal and neonatally androgenised female rats Peptides 1 (Supplement I) $85-100$

Liaw JJ and Barraclough CA (1993) $N$-methyl-D,L-aspartic acid differentially affects LH release and LHRH mRNA levels in estrogen-treated ovariectomized control and androgenized-sterilized rats Molecular Brain Research $17 \quad 112-118$

Lindström P and Ohlsson L (1992) Effect of N-methyl-D, L-aspartate on isolated rat somatotrophs Endocrinology 131 1903-1907

Lookingland KJ, Wise PM and Barraclough CA (1982) Failure of the hypothalamic noradrenergic system to function in adult androgen-sterilized rats Biology of Reproduction 27 268-281

López FJ, Donoso AO and Negro-Vilar A (1990) Endogenous excitatory amino acid neurotransmission regulates the estradiol-induced LH surge in ovariectomized rats Endocrinology 126 1771-1773

Luderer U, Strobl FJ, Levine JE and Schwartz NB (1993) Differential gonadotropin responses to $\mathrm{N}$-methyl-0,L-aspartate in metestrous, proestrous, and ovariectomized rats Biology of Reproduction 48 857-866

MacDonald MC and Wilkinson M (1992) Characterization and ontogenesis of $\mathrm{N}$-methyl-o-aspartate evoked luteinizing hormone secretion in immature female rats Journal of Neuroendocrinology 4 223-229

Mason GA, Bisette G and Nemeroff CB (1983) Effects of excitotoxic amino acids on pituitary hormone secretion in the rat Brain Research 289 366-369

Mennin SP and Gorski RA (1975) Effect of ovarian steroids on plasma LH in normal and persistent estrus adult female rats Endocrinology 96 486-491

Naftolin F, Ryan KJ, Davies IJ, Reddy VV, Flores F, Petro Z,Kuhn M, White RJ, Takaoka Y and Wolin L (1973) The formation of estrogen by central neuroendocrine tissues Recent Progress in Hormone Research 31 295-319

Ping L, Mahesh VB and Brann DW (1994a) Release of glutamate and aspartate from the preoptic area during the progesterone-induced LH surge: in vivo microdialysis studies Neuroendocrinology 59 318-324

Ping L, Mahesh VB and Brann DW (1994b) A physiological role for N-methylD-aspartic acid and non- $N$-methyl-D-aspartic acid receptors in pulsatile gonadotropin secretion in the adult female rat Endocrinology 135 113-118

Pinilla L, Tena-Sempere M and Aguilar E (1994) Effect of LHRH, Naloxone and $N$-methyl-D-aspartic acid on serum gonadotropin concentrations in neonatally estrogenized female rats Neuroendocrinology Letters 16 233-239

Pinilla L, Tena-Sempere $M$ and Aguilar E (1995) The role of excitatory amino acid pathways in the control of pituitary function in neonatally oestrogenized male rats Journal of Endocrinology 147 51-57

Price MT, OLney JW and Cicero TJ (1978) Acute elevations of serum luteinizing hormone induced by kainic acid, $N$-methyl aspartic acid or homocysteic acid Neuroendocrinology 26 352-358

Schainker BA and Cicero TJ (1980) Acute central stimulation of luteinizing hormone by parenterally administered $N$-methyl-D, $L$-aspartic acid in the male rat Bruin Research 184 425-437

Urbanski HF and Ojeda SR (1987) Activation of luteinizing hormone-releasing hormone release advances the onset of female puberty Neuroendocrinology 46 273-276

Vaticon MD, Fernandez-Galaz C, Tejero A and Aguilar E (1985) Alteration of prolactin control in adult rats treated neonatally with sex steroids Journal of Endocrinology 105 429-433

Vito CC and Fox TO (1982) Androgen and estrogen receptors in embryonic and neonatal rat brain Developmental Brain Research 2 97-100

Zanisi M, Galbiati M, Messi E and Martini L (1994) The anterior pituitary gland as a possible site of action of kainic acid Proceedings of the Society of Experimental Biology and Medicine 206 431-437 